\title{
Review \\ Clinical CYP2D6 Genotyping to Personalize Adjuvant Tamoxifen Treatment in ER-Positive Breast Cancer Patients: Current Status of a Controversy
}

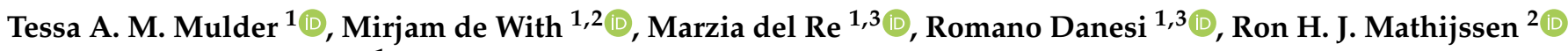 \\ and Ron H. N. van Schaik ${ }^{1, *}$ \\ 1 Department of Clinical Chemistry, Erasmus MC University Hospital, Wytemaweg 80, \\ 3015CN Rotterdam, The Netherlands; t.mulder@erasmusmc.nl (T.A.M.M.); \\ m.dewith@erasmusmc.nl (M.d.W.); marzia.delre@gmail.com (M.d.R.); romano.danesi@med.unipi.it (R.D.) \\ 2 Department of Medical Oncology, Erasmus MC Cancer Institute, Erasmus MC, Wytemaweg 80, \\ 3015CN Rotterdam, The Netherlands; a.mathijssen@erasmusmc.nl \\ 3 Clinical Pharmacology and Pharmacogenetics Unit, Department of Clinical and Experimental Medicine, \\ University of Pisa, 55, Via Roma, 56126 Pisa, Italy \\ * Correspondence: r.vanschaik@erasmusmc.nl; Tel.: +31-10-703-3119
}

Citation: Mulder, T.A.M.; de With, M.; del Re, M.; Danesi, R.; Mathijssen, R.H.J.; van Schaik, R.H.N. Clinical CYP2D6 Genotyping to Personalize Adjuvant Tamoxifen Treatment in ER-Positive Breast Cancer Patients: Current Status of a Controversy. Cancers 2021, 13, 771. https:// doi.org/10.3390/cancers13040771

Academic Editor: Daniel L. Hertz

Received: 14 January 2021

Accepted: 8 February 2021

Published: 12 February 2021

Publisher's Note: MDPI stays neutral with regard to jurisdictional claims in published maps and institutional affiliations.

Copyright: (C) 2021 by the authors Licensee MDPI, Basel, Switzerland. This article is an open access article distributed under the terms and conditions of the Creative Commons Attribution (CC BY) license (https:// creativecommons.org/licenses/by/ $4.0 /)$.
Simple Summary: Tamoxifen is an important adjuvant endocrine therapy in estrogen receptor (ER)positive breast cancer patients. It is mainly catalyzed by the enzyme CYP2D6 into the most active metabolite endoxifen. Genetic variation in the CYP2D6 gene influences endoxifen formation and thereby potentially therapy outcome. However, the association between CYP2D6 genotype and clinical outcome on tamoxifen is still under debate, as contradictory outcomes have been published. This review describes the latest insights in both CYP2D6 genotype and endoxifen concentrations, as well CYP2D6 genotype and clinical outcome, from 2018 to 2020.

Abstract: Tamoxifen is a major option for adjuvant endocrine treatment in estrogen receptor (ER) positive breast cancer patients. The conversion of the prodrug tamoxifen into the most active metabolite endoxifen is mainly catalyzed by the enzyme cytochrome P450 2D6 (CYP2D6). Genetic variation in the CYP2D6 gene leads to altered enzyme activity, which influences endoxifen formation and thereby potentially therapy outcome. The association between genetically compromised CYP2D6 activity and low endoxifen plasma concentrations is generally accepted, and it was shown that tamoxifen dose increments in compromised patients resulted in higher endoxifen concentrations. However, the correlation between CYP2D6 genotype and clinical outcome is still under debate. This has led to genotype-based tamoxifen dosing recommendations by the Clinical Pharmacogenetic Implementation Consortium (CPIC) in 2018, whereas in 2019, the European Society of Medical Oncology (ESMO) discouraged the use of CYP2D6 genotyping in clinical practice for tamoxifen therapy. This paper describes the latest developments on CYP2D6 genotyping in relation to endoxifen plasma concentrations and tamoxifen-related clinical outcome. Therefore, we focused on Pharmacogenetic publications from 2018 (CPIC publication) to 2021 in order to shed a light on the current status of this debate.

Keywords: tamoxifen; Pharmacogenetics; PGx; CYP2D6; Cytochrome P450 2D6; genotyping; tamoxifen treatment; review

\section{Introduction}

For many years, tamoxifen has been known as the most important adjuvant endocrine treatment in patients with estrogen receptor (ER) positive breast cancer $[1,2]$. It is a selective estrogen receptor modulator (SERM), which inhibits tumor growth and promotes apoptosis in ER-positive tumors [3], resulting in a reduced risk of recurrence and death from breast cancer [4]. Tamoxifen is metabolized into its most active antiestrogenic metabolite 
endoxifen, predominantly by cytochrome P450 2D6 (CYP2D6). Despite high efficacy, a wide variability in the response of individuals to standard doses of tamoxifen is seen [4]. Factors influencing drug responses such as gender, age, obesity, drug-drug interactions, drug-food interactions, comorbidity, liver and renal function, pregnancy, circadian rhythm, as well as genetic factors could possibly explain this wide variability [5-10].

As genetic variation in CYP2D6 leads to altered enzyme activity and thereby potentially to an affected efficacy [5], pharmacogenetic (PGx) testing could play a major role in optimizing tamoxifen treatment. Nowadays, PGx testing is available for an increasing number of drugs, mainly in psychiatric but also for cardiologic and oncologic applications. However, only a small number of drugs are considered to require upfront genotyping, such as HLA-B*5701 genotyping for abacavir, CYP2C19 genotyping for clopidogrel, and $D P Y D$ testing for fluoropyrimidines treatment [11-13]. The challenge of PGx testing is to obtain actionable information of genetic variants and their influence on outcome. Experts differ in their interpretation of published evidence and their recommendations [5]. This also applies to tamoxifen. Whereas the first studies on CYP2D6 genotyping for optimizing tamoxifen therapy based on pharmacokinetic studies [14] or outcome $[15,16]$ were published in 2005, its clinical implementation is still being debated $[17,18]$. The controversy was most prominently seen in 2012. At that time, two studies were published, and both concluded there was no significant association between CYP2D6 genotype and outcome in breast cancer patients treated with adjuvant tamoxifen therapy $[19,20]$. This triggered several researchers with opposite visions, leading to a correspondence as published in the JNCI [21-24]. In 2013, several meta-analyses were performed in order to answer the question of whether CYP2D6 status affects clinical outcomes in tamoxifen therapy [25-29]. However, also these findings yielded contradictory results. In 2018, the Clinical Pharmacogenetics Implementation Consortium (CPIC) published a recommendation on CYP2D6 genotyping for guiding adjuvant tamoxifen therapy, thus supporting the importance of the CYP2D6 genotype in tamoxifen therapy. However, the European Society for Medical Oncology (ESMO) indicated in a publication in 2019 that according to their view, there was no place for CYP2D6 genotyping in a clinical setting [18].

According to predictions, over 3 million women will be diagnosed with breast cancer in 2040 [30], which triggers the strong need for optimizing tamoxifen treatment. Therefore, the primary objective of this review is to discuss new data on CYP2D6 genotyping in breast cancer patients treated with tamoxifen. In addition, we included some other factors influencing plasma concentrations of tamoxifen and its metabolites. We searched for relevant studies published from 2018 (publication CPIC) to 2021 on CYP2D6 genotype in relation to endoxifen levels and tamoxifen-related clinical outcome.

\section{Tamoxifen Metabolism}

Tamoxifen is a prodrug, which is converted into multiple derivatives by phase I enzymes. Among these, 4-hydroxytamoxifen (4OH-TAM) and endoxifen show the strongest affinity with the ER [2,31]. As the plasma concentration of endoxifen is 6 to 12 times higher compared with 4OH-TAM, and endoxifen has the lowest IC50 at the ER, endoxifen is considered the major active tamoxifen metabolite [2,31]. Tamoxifen is $\mathrm{N}$-demethylated, predominantly by CYP3A4 and CYP3A5, resulting in inactive $\mathrm{N}$-desmethyltamoxifen (NDM-TAM) (Figure 1). 4-hydroxylation of NDM-TAM is nearly exclusively performed by CYP2D6, resulting in the formation of 4-hydroxy- $\mathrm{N}$-desmethyltamoxifen, also known as endoxifen [2,31]. As shown in Figure 1, demethylation and hydroxylation can also occur in the opposite order, resulting a different intermediate metabolite called 4-hydroxytamoxifen (4OH-TAM) [2,31]. As NDM-TAM is the primary metabolite regarding plasma concentrations, the demethylation followed by hydroxylation is supposed to be the main route [32]. 


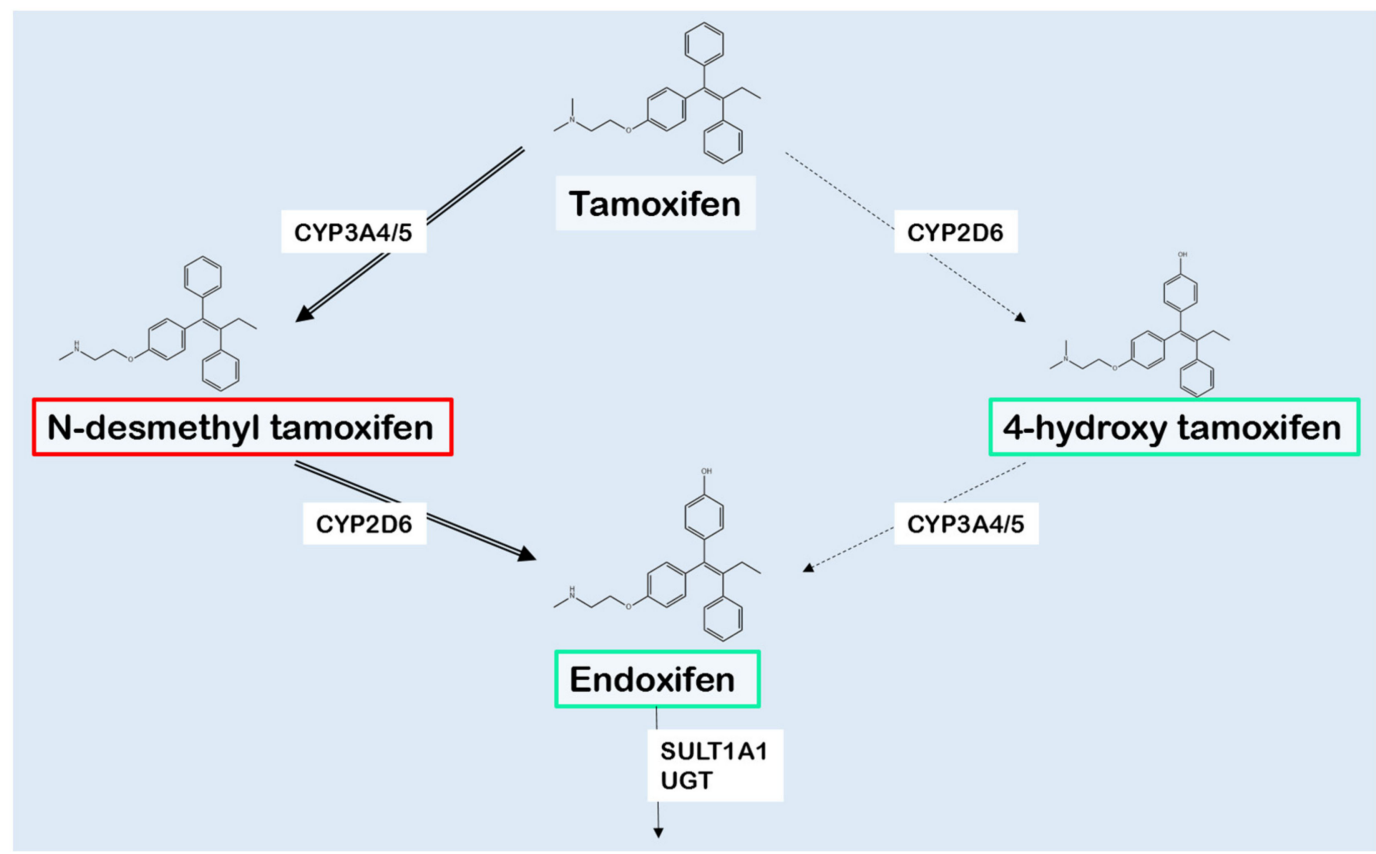

Figure 1. Simplistic representation of the main biotransformation of tamoxifen and its metabolites. The generation of $\mathrm{N}$-desmethyltamoxifen (NDM-TAM) is predominantly catalyzed by CYP3A4/5, whereas especially CYP2D6 is responsible for the formation of 4-hydroxytamoxifen (4OH-TAM) and endoxifen. The activity of metabolites is shown using red to indicate for inactivity and green for activity. The various metabolites are inactivated by UGTs and SULTs, mainly isoform SULT1A1. Abbreviations: CYP: Cytochrome P450 isoenzymes, UGT: UDP-glucuronosyltransferase, SULT: sulfotransferase isoenzyme. Figure based on Jin, et al. [14].

\section{Cytochrome P450 2D6}

CYP2D6 is involved in the metabolism of $\approx 25 \%$ of the most commonly used drugs, whereas it only accounts for approximately $2 \%$ of total liver CYP protein capacity $[2,33]$. As shown in Figure 1, CYP2D6 is responsible for the specific conversion of NDM-TAM to endoxifen [31]. Therefore, CYP2D6 is considered the most important drug-metabolizing enzyme in tamoxifen metabolism. The CYP2D6 gene is located on chromosome 22q13.2 and is highly polymorphic [34]. Currently, approximately 150 single nucleotide polymorphisms (SNPs) and 100 allelic variants are described [35]. Genetic polymorphisms may result in non-functional or reduced function alleles. Copy number variations, such as CYP2D6 gene deletions and CYP2D6 gene duplications, also occur [31,36]. This genetic variability results in individuals showing a broad spectrum of enzyme activities, indicated as poor (PM), intermediate (IM), normal (NM) or ultra-rapid metabolizers (UM) based on genetic composition $[17,36]$. Another approach is to use Activity Scores (AS), in which normal alleles are assigned a value of 1.0, decreased activity alleles are assigned a score of 0.5 , and null alleles are assigned a score of 0.0 [17]. Genetic variants can be specific for certain populations and rarely found in other populations [33,37]. The variation in allele frequency results in differences in metabolic CYP2D6 activity amongst ethnic groups [33].

A translation of CYP2D6 genotype into predicted CYP2D6 phenotype is shown in Table 1. Important changes were published in 2019, where it was internationally agreed to harmonize the CYP2D $6^{*} 1 /{ }^{*} 4$ interpretation from an Extensive/Normal metabolizer phenotype (CPIC definition until 2017, mostly used in US) into an Intermediate Metabolizer phenotype (definition used by the Dutch Pharmacogenetics Working Group (DPWG), which is mostly used in Europe). The second important change concerns the CYP2D ${ }^{*} 10$ allele, which was downgraded from AS $=0.5$, comparable to other decreased activity alleles such as ${ }^{*} 9$ and ${ }^{*} 41$, to AS $=0.25[38,39]$. 
Table 1. Adapted final consensus CYP2D6 genotype to phenotype table. Combining the previous CPIC and DPWG guidelines and adding new pharmacogenetic insights [38]. Abbreviations: CYP2D6: Cytochrome P450 2D6, UM: ultra-rapid metabolizer, NM: normal or extensive metabolizer, IM: intermediate metabolizer, PM: poor metabolizer, CPIC: Clinical Pharmacogenetic Implementation Consortium, DPWG: Dutch Pharmacogenetics Working Group.

\begin{tabular}{cccc}
\hline Likely Phenotype & $\begin{array}{c}\text { CURRENT CPIC } \\
\text { Activity Score Definition }\end{array}$ & $\begin{array}{c}\text { CURRENT DPWG } \\
\text { Activity Score Definition }\end{array}$ & $\begin{array}{c}\text { NEW Standardized } \\
\text { Activity Score Definition }\end{array}$ \\
\hline CYP2D6 UM & $>2$ & $>2.5$ & $>2.25$ \\
CYP2D6 NM & $1-2$ & $1.5-2.5$ & $1.25-2.25$ \\
CYP2D6 IM & 0.5 & $0.5-1.0$ & $0.25-1.0$ \\
CYP2D6 PM & 0 & 0 & 0 \\
\hline
\end{tabular}

Most recently, Lee et al. suggested a dichotomization into normal and slow metabolizer CYP2D6 groups in an effort to improve and simplify the current system [40]. Nonetheless, these authors also recommend considering the direct measurement of endoxifen plasma concentrations, as CYP2D6 genotype is not solely responsible for systemic endoxifen levels. In line with this recommendation, several authors [41-44] as well as the CPIC tamoxifen guideline [17] suggest that individualized dosing (e.g., therapeutic drug monitoring, TDM) might be a better option, instead of using a standard dosage of $20 \mathrm{mg}$ tamoxifen per day. Another option is direct phenotyping, using dextromethorphan as a CYP2D6 phenotyping probe [45-47]. The advantage of this approach is that no genotype to phenotype translation is required, and that dose adjustment can be determined before the start of therapy [47]. Nevertheless, there are many more metabolites with unknown or estrogen-like properties [48]. Therefore, tamoxifen dosing solely based on (predicted) endoxifen blood concentrations might not be the best approach.

\section{Influence of Other Drug Metabolizing Enzymes}

In addition to CYP3A4/5 and CYP2D6, other CYP enzymes such as CYP2C9, CYP2C19, and CYP3A4 are involved in the tamoxifen metabolism. It is shown that genetic variation in these genes affects tamoxifen and metabolite plasma concentrations [49-58], although not all studies support these associations [59-62]. Several groups [59,61,62] examined the effect of variation in multiple CYP genes, but all concluded that only genetic variation in CYP2D6 was associated with plasma concentrations of endoxifen.

The most important phase II enzymes in tamoxifen metabolism are uridine $5^{\prime}$-diphosphoglucuronosyltransferases (UGTs) and sulfotransferases (SULTs), primarily SULT1A1 [31,63]. Associations between genetic variation in UGTs or SULT1A1 and lower enzymatic activity [64], higher plasma levels of tamoxifen metabolites [65,66], or worse clinical outcome [66] were published. Therefore, these findings highlight the potential influence of UGTs and SULTs on tamoxifen disposition in breast cancer patients. In this light, the influence of the UGT inhibitor probenecid on tamoxifen metabolism is currently under investigation, and the results of this study are expected in 2021 (see Dutch Trial Registry: https:/ / www.trialregister.nl/trial/8444, accessed on 28 November 2020). It is important to keep in mind that many enzymes may simultaneously influence the plasma levels of tamoxifen and its metabolites and therefore may also influence tamoxifen treatment efficacy.

\section{Factors Affecting Endoxifen Levels}

Madlensky et al. [67] reported in 2011 that patients with endoxifen levels $>5.97 \mathrm{ng} / \mathrm{mL}$ $(\approx 16 \mathrm{nM})$ had a $26 \%$ lower relative risk of breast cancer recurrence (hazard ratio (HR): 0.74 ; $95 \%$ confidence interval (CI) 0.55-1.00). In 2015, a comparable threshold for tamoxifen efficacy of plasma endoxifen at $5.2 \mathrm{ng} / \mathrm{mL}$ was described [50]. However, this threshold was questioned, because the study was not designed to determine this endoxifen threshold [68,69]. In 2020, in all homozygous carriers of CYP2D6 non-functional alleles, but also in carriers of two reduced function alleles, significantly reduced endoxifen levels were observed [70]. A total of 118 Swedish premenopausal breast cancer patients genotyped 
for nine different allelic variants using blood as a source of genomic DNA showed that the endoxifen concentration in $32 \%$ of patients did not reach this putative threshold. Both NMs as well as UMs had endoxifen levels higher than the threshold of $5.9 \mathrm{ng} / \mathrm{mL}$. Median endoxifen levels were 9.60 (interquartile range (IQR): 7.5-12.2) for normal or extensive metabolizers (NMs) and 12.8 (IQR: 9.7-16.0) $\mathrm{ng} / \mathrm{mL}$ for ultra-rapid metabolizers (UMs). Poor metabolizers (PMs) and intermediate metabolizers (IMs) had endoxifen concentrations below this level (1.6-5.2 ng/mL). Interestingly, there was no statistical difference in endoxifen levels between PMs carrying two non-functional alleles and patients with the two decreased activity alleles ${ }^{*} 41{ }^{*} 41$ or the combination ${ }^{*} 41$ /non-functional (defined as IM).

Nardin et al. [71] also confirmed in 2020 that tamoxifen metabolite levels were affected by the CYP2D6 genotype, with the strongest effect for endoxifen concentrations. PMs carrying two non-functional alleles had 4.5 to 5.5 times lower endoxifen concentrations than NMs carrying two functional alleles. This study was conducted in 192 Brazilian breast cancer patients with endoxifen concentrations measured at 3, 6, and 12 months after the start tamoxifen treatment. Additionally, CYP2D6 phenotypes significantly predicted tamoxifen metabolite levels across all time points in multivariate analyses [71].

Taken together, these studies [70,71] confirmed that CYP2D6 metabolizer status is a strong determinant of endoxifen plasma concentration and that increasing CYP2D6 allele activity correlates with increasing plasma levels.

\subsection{Tamoxifen Dose Escalation and Endoxifen Levels}

Breast cancer patients with lower endoxifen levels than the published efficacy threshold of $5.9 \mathrm{ng} / \mathrm{mL}$ might benefit from a higher dose tamoxifen than the standard $20 \mathrm{mg} /$ day. Khalaj et al. [72] performed a prospective clinical trial with a total of 134 Iranian ERpositive breast cancer patients. Patients with AS $=1(n=15)$ and AS $=0-0.5(n=2)$ received dose-adjusted therapy of 30 and $40 \mathrm{mg} /$ day, respectively. Before dose escalation, the mean endoxifen concentration differed significantly between genetic phenotype groups, and a correlation between plasma endoxifen concentrations and CYP2D6 activity was observed, although considerable inter-individual variability within the metabolizer groups was present [72]. Dose adjustment in patients with AS $=0-1$ also resulted in a significant increase in median endoxifen plasma concentrations, from $11.9 \mathrm{nM}$ at baseline to 23.5 $\mathrm{nM}$ after 8 months [72]. This resulted in comparable endoxifen plasma concentrations as compared to patients with AS > 1 receiving the standard dose of $20 \mathrm{mg} /$ day.

Tamura et al. [73] investigated the effect of CYP2D6 genotype-guided tamoxifen dosing in a randomized, open-label, phase II study, in which 186 Japanese breast cancer patients were genotyped. Patients carrying at least one CYP2D6 variant allele were randomly assigned to two groups: regular tamoxifen dosage (RD, $n=66,20 \mathrm{mg} /$ day) and increased tamoxifen dosage (ID, $n=70,40 \mathrm{mg} /$ day). This resulted in a significantly higher median serum through endoxifen concentration in the ID group as compared to the regular dose (RD) group [73]. In 2011, Irvin et al. [74] also demonstrated that dose escalation to $40 \mathrm{mg}$ tamoxifen/day in American PM and IM breast cancer patients resulted in higher endoxifen plasma levels, as compared to PM and IM patients receiving the standard dose. The median plasma concentration increased by a factor of 1.2 in IMs and 3.1 in PMs. In 2015, Welzen et al. [75] performed a similar study in four PM and 12 IM breast cancer patients after tamoxifen dose adjustment from 20 to $40 \mathrm{mg} /$ day. This showed an increment in median plasma concentration of endoxifen by a factor of 2.05 in PMs and by a factor of 1.83 in IMs. Nevertheless, after dose adjustment, there was still a significant difference remaining in endoxifen concentrations between NM and PM patients in both studies [74,75]. In 2015, Martinez de Dueñas et al. [76] showed similar levels of endoxifen concentrations in PM patients after dose escalation to $40 \mathrm{mg} /$ day $(n=11)$ and subsequently to $60 \mathrm{mg} /$ day $(n=8)$, and NM patients were treated with the standard tamoxifen dose. After increase of the dosage, no significant increase in the occurrence of the most common side effect (hot flashes) or severe side effects was found [72,73]. Meanwhile, the frequency of vomiting 
and agitation did increase, although only slightly [72]. This finding was in contrast with the previous studies [74-76], which reported no difference in the occurrence of side effects.

Currently, in the Netherlands, a large prospective clinical trial is ongoing in early stage ER-positive breast cancer patients, in order to assess the feasibility of TDM-guided dosing of tamoxifen in clinical practice (the TOTAM study). In this study, patients are genotyped for CYP2D6 polymorphisms, and endoxifen concentrations are determined 3 months after the start of tamoxifen treatment (https://www.trialregister.nl/trial/6918, accessed on 28 November 2020). Patients with endoxifen levels below $16 \mathrm{nM}(\approx 5.97 \mathrm{ng} / \mathrm{mL})$ receive a dose adjustment of tamoxifen. Subsequently, endoxifen concentrations were monitored during a period of 2 years. The first positive results have recently been presented at the ESMO virtual congress 2020 and confirm that TDM-guided dosing is feasible in order to optimize endoxifen levels [77].

\subsection{Patient Therapy Adherence and Endoxifen Levels}

The plasma concentration of endoxifen is affected by many factors (Figure 2). An important factor is treatment adherence. It is seen that breast cancer patients stop tamoxifen treatment before completing the standard treatment period of 5 years. Reasons for quitting early are the development of side effects, suboptimal patient physician communication, or low perception of the tumor recurrence risk [71]. Multivariate analyses showed that about $47 \%$ of tamoxifen plasma concentration variability is explained by patient adherence behavior; in addition, the combination of CYP2D6 genotype and adherence behavior explained $40 \%$ of endoxifen plasma concentration variability at 12 months [71].

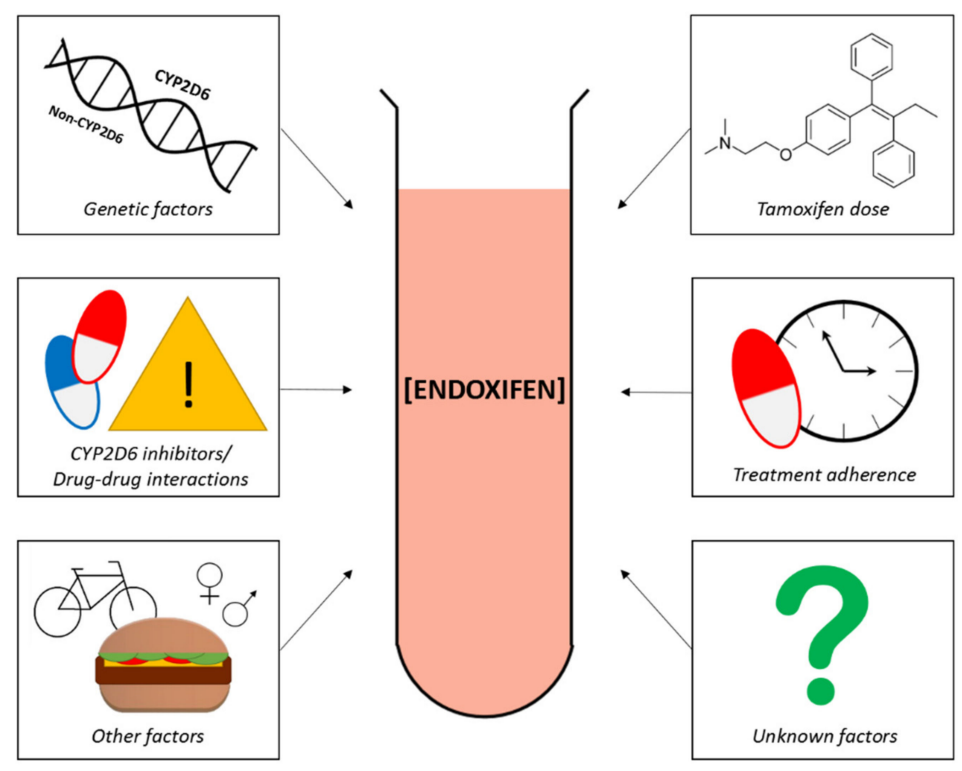

Figure 2. Schematic overview of factors influencing plasma concentrations of endoxifen. Known factors are genetic influences (e.g., CYP2D6 polymorphisms but also non-CYP2D6 polymorphisms), drug-drug interactions (e.g., concomitant use of CYP2D6 inhibitors), other factors (e.g., food, lifestyle, gender, age), tamoxifen dose, treatment adherence, and additional unknown factors.

He et al. [78] investigated the relationship between CYP2D6 metabolizer status and tamoxifen discontinuation in a prospective-retrospective study, showing that UMs had a discontinuation rate of $18.8 \%$ at 6 months after the start of tamoxifen treatment. This was significantly higher than the discontinuation rate of NMs (6.7\%) [78]. At the same time point, no significant difference in tamoxifen discontinuation was found for PMs (7.1\%) or IMs $(7.6 \%)$, as compared to NMs (6.7\%) [78]. 


\subsection{Drug-Drug Interactions}

Drug-drug interactions (DDIs) represent one of the major confounding factors for the evaluation of drug efficacy, and their clinical relevance is not always thoroughly investigated $[79,80]$. As tamoxifen is co-prescribed with CYP2D6 inhibitors, as shown by Arafah et al. in 499 Saudi patients [81], it is of critical importance to understand if and how concomitant treatment with CYP2D6 inhibitors can influence tamoxifen and metabolite levels.

Borges et al. [82] prospectively enrolled 158 tamoxifen-treated patients, analyzed the CYP2D6 genotype, and measured plasma concentrations of tamoxifen and its metabolites. It seems endoxifen plasma concentrations were significantly lower in CYP2D6 NMs with the concomitant use of (strong) CYP2D6 inhibitors as compared to those without the concomitant use of CYP2D6 inhibitors ( $23.5 \pm 9.5 \mathrm{nM}$ vs. $84.1 \pm 39.4 \mathrm{nM}$, respectively) [82]. Similar results are shown if tamoxifen is concomitant used with selective serotonin reuptake inhibitors (SSRIs) [14]. In this study, endoxifen levels in NMs taking CYP2D6 inhibitors were $58 \%$ lower than in patients who did not use CYP2D6 inhibitors [14]. In a prospective trial, including patients treated with adjuvant tamoxifen, the influence of concomitant paroxetine use was studied [83]. Measuring plasma levels of tamoxifen and its metabolites in 12 women, before and after 4 weeks of paroxetine co-administration, showed significant lower endoxifen concentrations if tamoxifen is concomitantly used with paroxetine (from a mean of $12.4 \mathrm{ng} / \mathrm{mL}$ to $5.5 \mathrm{ng} / \mathrm{mL}$ ) [83]. In addition, Binkhorst et al. [6] showed that switching patients using tamoxifen from a strong SSRI to a minor SSRI resulted in dramatically increased endoxifen concentrations. Monte et al. [84] showed in a prospective study that the co-administration of a CYP2D6-dependent probe drug (dextromethorphan) resulted in a 9.49 times higher chance of genotype-phenotype discordance based upon $3 \mathrm{~h}$ DX/DM ratio [84].

These studies indicate an important role of DDIs on tamoxifen activation. Treating physicians should take this into account in order to minimize deleterious interactions that may reduce drug efficacy [85].

Studies regarding the CYP2D6 genotype and additional factors on plasma concentration endoxifen described in this section are summarized in Table 2.

Table 2. Summary of described recent studies on CYP2D6 genotyping, and additional factors on plasma concentrations endoxifen.

\begin{tabular}{|c|c|c|c|c|}
\hline Reference & End-Point & N. PTS. & Material and Methods & Results \\
\hline $\begin{array}{l}\text { Thorén et al., } 2020 \text { [70] } \\
\text { Nardin et al., } 2020 \text { [71] }\end{array}$ & $\begin{array}{l}\text { Endoxifen plasma } \\
\text { concentrations in PM, IM, } \\
\text { NM, and UM patients }\end{array}$ & 118,192 & $\begin{array}{l}\text { CYP2D6 genotyping; } \\
\text { LC-MS/MS }\end{array}$ & $\begin{array}{l}\text { CYP2D6 metabolizer status is a strong determinant } \\
\text { of plasma endoxifen concentrations. Increasing } \\
\text { CYP2D } 6 \text { allele activity correlates with increasing } \\
\text { endoxifen levels. }\end{array}$ \\
\hline $\begin{array}{l}\text { Khalaj et al., } 2019 \text { [72] } \\
\text { Tamura et al., [73] }\end{array}$ & $\begin{array}{l}\text { Endoxifen plasma } \\
\text { concentrations in PM, IM, } \\
\text { NM, and UM patients }\end{array}$ & 134,186 & $\begin{array}{l}\text { CYP2D6 genotyping; } \\
\text { LC-MS/MS }\end{array}$ & $\begin{array}{l}\text { Dose escalation in CYP2D6-compromised patients } \\
\text { (PMs and IMs combined) resulted in an increase in } \\
\text { endoxifen levels, similar as NMs (using standard } \\
\text { dosage of } 20 \mathrm{mg} / \text { day). No difference in the } \\
\text { occurrence of the most common side effect (hot } \\
\text { flushes) or severe side effects was found. }\end{array}$ \\
\hline Nardin et al., 2020 [71] & $\begin{array}{l}\text { Endoxifen plasma } \\
\text { concentrations in PM, IM, } \\
\text { NM and UM patients; Patient } \\
\text { adherence behavior }\end{array}$ & 192 & $\begin{array}{l}\text { CYP2D6 genotyping; } \\
\text { LC-MS/MS; Morisky, } \\
\text { Green, and Levine } \\
\text { medication adherence scale }\end{array}$ & $\begin{array}{l}\text { Adherence explained } 47 \% \text { of tamoxifen variability ( } p \\
<0.001) \text {. Combination of patients adherence and } \\
\text { CYP2D6 genotype explained } 40 \% \text { of endoxifen } \\
\text { variability at } 12 \text { months }(p<0.001) \text {. So, endoxifen } \\
\text { levels are influenced both by patients' tamoxifen } \\
\text { treatment adherence and CYP2D6 genotype. }\end{array}$ \\
\hline He et al., 2020 [78] & Tamoxifen discontinuation & 1309 & $\begin{array}{l}\text { CYP2D6 genotyping; } \\
\text { Self-reported } \\
\text { questionnaires }\end{array}$ & $\begin{array}{l}\text { UMs show a significantly higher discontinuation rate } \\
\text { at } 6 \text { months after start of tamoxifen treatment }(18.8 \%) \\
\text { compared to NMs (6.7). No significant difference in } \\
\text { tamoxifen discontinuation was found for PMs }(7.1 \%) \\
\text { or IMs ( } 7.6 \%) \text {. After } 6 \text { months, no significant } \\
\text { difference in discontinuation rates was found. }\end{array}$ \\
\hline Monte et al., 2018 [84] & $\begin{array}{c}\text { Dextro-methorphan } \\
\text { (DM)/dextror-phan (DX) } \\
\text { ratio in PM, IM, NM, and UM } \\
\text { patients }\end{array}$ & 39 & $\begin{array}{c}\text { CYP2D6 genotyping; } \\
\text { Plasma DM and DX assay } \\
\text { using LC-MS }\end{array}$ & $\begin{array}{l}\text { Patients with co-ingestion of dextromethorphan (as } \\
\text { CYP2D6 enzyme probe drug) and another } \\
\text { CYP2D6-dependent drug were } 9.5 \text { times more likely } \\
\text { to have genotype-phenotype discordance based upon } \\
\text { the } 3 \text { h DX/DM ratio. }\end{array}$ \\
\hline
\end{tabular}




\section{CYP2D6 Genotype and Outcome}

The main goal of preemptive CYP2D6 genotyping is improving tamoxifen treatment outcome. As summarized in 2009 by Dezentje et al. [86], studies published up to 2009 showed contradictory results. In 2018, a CPIC guideline on CYP2D6 and tamoxifen was published [17], indicating an added value of CYP2D6 genotyping prior to tamoxifen therapy as assessed by this international group of experts. However, in 2019, the European Society for Medical Oncology (ESMO) strongly argues against the use of the CYP2D6 genotype for determining tamoxifen dosage in a clinical setting [18]. We reviewed the literature for publications from 2018 to 2021 on CYP2D6 and clinical outcome to see if new information has arisen.

\subsection{Positive Association CYP2D6 Genotype and Outcome}

In 2018, Brooks et al. [87] showed that CYP2D6 genotype was associated with breast cancer recurrence in patients treated with tamoxifen in an adjuvant setting. The CYP2D6 genotype was determined in two groups of predominantly non-Hispanic white patients; 1514 contralateral breast cancer (CBC) cases and 2203 unilateral breast cancer controls. CYP2D6 NM patients with a first breast cancer and treated with tamoxifen had nearly a $40 \%$ lower risk of CBC compared to patients without tamoxifen treatment (AS $\geq 1$, RR $=0.63 ; 95 \%$ CI 0.51-0.78). The risk of CBC in IMs and PMs (AS < 1) was not reduced by tamoxifen treatment ( $R R=0.95$ and $R R=1.18$, respectively) as compared to IMs and PMs without tamoxifen treatment [87]. Despite a higher AS seemingly associated with a decreased recurrence risk of $\mathrm{CBC}$, there was no significant difference in RR found between the metabolizer groups. The lack of information on CYP2D6 copy number variations is an important limitation of this study; thereby, no identification of UMs was possible within the study population.

A prospective cohort study in 157 Egyptian metastatic breast cancer patients investigated the influence of CYP2D6 polymorphisms on tamoxifen response after 6 months of tamoxifen treatment. Thirty carriers of CYP2D 6 variant alleles had progression within 6 months after the start of tamoxifen treatment, whereas fourteen patients achieved good clinical tamoxifen response after 6 months [88]. This suggests that patients with metastatic breast cancer carrying certain CYP2D6 variant alleles have worse 6-month prognosis after tamoxifen treatment. A limitation of this study is the limited amount of allele variants $(n=$ 4) genotyped, thereby increasing the chances of missing patients carrying non wild-type alleles. Tamoxifen is used as a treatment option for metastatic breast cancer instead of adjuvant therapy.

He et al. [78] examined the association between CYP2D6 genotype and breast cancer prognosis in 1309 Swedish breast cancer patients treated with tamoxifen. HRs were calculated in order to determine the association between CYP2D6 metabolizer status and breast cancer-specific mortality. This resulted in an HR of 2.59 for PMs (95\% CI 1.01-6.67), 1.48 for IMs (95\% CI 0.72-3.05), 1 for NMs (reference), and 4.52 for UMs (90\% CI 1.42-14.37) [78]. Thus, both PMs and UMs have a worse prognosis for breast cancer compared to NMs after receiving a standard dose of tamoxifen. Other studies already provided evidence that PMs have a lower endoxifen level than NMs; therefore, worse prognosis is expected [70,71]. Unlike PMs, UMs are expected to have a higher endoxifen level as compared to NMs and therefore should have a tamoxifen response after standard tamoxifen dosage. An explanation for the high HR for UMs might be higher endoxifen plasma concentrations, resulting in a higher frequency of adverse drug reactions (ADRs) and thereby higher discontinuation rates. It was shown that symptom-relieving drugs such as antinauseants, anxiolytics, and medications against hot flashes were more often used by UMs than by NMs [78]. Of note, no significant difference was found for PM and IMs compared to NMs for the use of symptom-relieving drugs. Additional analyses revealed that users of symptom-relieving drugs showed higher tamoxifen discontinuation rates [78]. There was a higher number of breast cancer mortality among patients who discontinued tamoxifen treatment [78]. Due to 
the low proportion of UMs in the population, the study was underpowered to determine underlying causes of higher breast-cancer specific mortality rates in this specific group.

\subsection{No Association CYP2D6 Genotype and Outcome}

In 2019, Sanchez-Spitman et al. [89] conducted a prospective clinical study in which 667 Dutch or Belgian breast cancer patients treated with adjuvant tamoxifen were enrolled. After CYP2D6 genotyping, patients were classified into five different groups; UMs, NMs, hetEM (heterozygous EMs), IMs, and PMs. Patients with two fully active alleles were classified as NM, whereas patients with one fully active and one non-functional allele were classified as hetEM. The 3-year relapse-free survival (RFS) was compared between the combined group of PMs, IMs, and hetEMs $(n=316)$, and the combined group of NMs and UMs $(n=322)$. Univariable analysis showed no difference in RFS between the two combined groups [89]. Classification, either based on the suggested threshold of $5.9 \mathrm{ng} / \mathrm{mL}$ or by quartile, did not result in any significant association between endoxifen levels and RFS [89]. This study received criticism by various researchers. Goetz et al. [90], Brauch et al. [91], and Braal et al. [92] stated that there were major issues regarding study design and statistical power. Firstly, patients included in this study received additional systemic therapy or switched to aromatase inhibitors instead of tamoxifen monotherapy in adjuvant setting. This may alter hazard for both early and late breast cancer events [90]. In addition, the anticipated effect size of $\mathrm{HR}=2.0$ at 3 years was said to be overestimated, since studies with a longer clinical follow-up of 5 and 10 years were at the basis for this HR [91]. Moreover, the study was not powered to investigate the relationship between endoxifen concentrations and clinical outcome [92]. Gusella et al. [47] stated that given the long time to recurrence of breast cancer, the short therapy duration and short followup might explain the negative results of this study. Moreover, the differences between the individual phenotype groups were not investigated. Of note, according the CPIC guidelines, hetEMs should have been classified as IMs; however, since hetEMs and IMs were combined in the same subgroup, this misclassification had a limited impact. A lack of impact of CYP2D6 genotype on breast cancer-free survival (BCFS) was also reported by Rangel-Méndez et al. [93]. In this retrospective study, in 71 Mexican Mestizo patients receiving adjuvant tamoxifen treatment $(20 \mathrm{mg} /$ day $)$, there was no statistical difference found in BCFS and recurrence risk between the NM/UM group $(n=56)$ and PM/IM group $(n=15)$ [93]. The limited sample size may have hindered the ability to find a significant association in this study [93].

Hertz et al. [94] conducted a retrospective PGx analysis based on 469 ER-positive Caucasian breast cancer patients treated with adjuvant tamoxifen monotherapy to investigate the association between low-activity CYP2D6 genotype and recurrence-free survival (RFS). Patients with AS $=0$ (PMs) and patients with AS >0 (IM, NM, and UM) were compared; however, no association of CYP2D6 status with RFS was found. After adjustment for relevant clinical covariates, analyses showed that a higher AS was associated with inferior RFS (HR: $1.43 ; p=0.05$ ). In 476 breast cancer patients who did not receive adjuvant tamoxifen therapy, an AS $>0$, as well as an increasing AS, were associated with superior RFS (HR $=0.41$ and $\mathrm{HR}=0.66$, respectively; $p=0.0015)$.

Tamura et al. [73] examined the effect of CYP2D6 genotype-guided tamoxifen dosing on progression-free survival (PFS) in 186 Japanese breast cancer patients. The PFS rates at 6 months did not differ between the increased dosage (ID) group (67.6\%) and the regular dose (RD) group (66.7\%). PFS curves of both arms did not significantly differ [73]. The 6 months PFS rate might not be adequate to assess the response by endocrine treatment of ER-positive metastatic breast cancer. Additionally, in this study, but also in the study of Sanchez-Spitman et al. [89] and Rangel-Méndez et al. [93], they did not make a distinction between non-functional and reduced function CYP2D6 variant alleles. This resulted in combining PMs and IMs in the intervention arm.

Publications from 2018 to 2021 on CYP2D6 and clinical outcome described in this section are summarized in Table 3. 
Table 3. Summary of described recent studies on CYP2D6 genotyping in relation to tamoxifen-related clinical outcome.

\begin{tabular}{|c|c|c|c|c|}
\hline Reference & End-Point & N. PTS. & Material and Methods & Results \\
\hline Brooks et al., 2018 [87] & $\begin{array}{l}\text { Recurrence risk of } \\
\text { contralateral breast cancer }\end{array}$ & $\begin{array}{c}1514 \\
\text { cases, } \\
2203 \\
\text { controls }\end{array}$ & $\begin{array}{l}\text { CYP2D6 genotyping; } \\
\text { population based } \\
\text { case-control study. }\end{array}$ & $\begin{array}{l}\text { No significant difference in recurrence risk between } \\
\text { metabolizer groups }(p=0.09) \text {. However, a trend of } \\
\text { decreasing CBC RR associated with tamoxifen } \\
\text { treatment, with increasing AS was shown. }\end{array}$ \\
\hline Malash et al., 2020 [88] & $\begin{array}{l}\text { Frequency of CYP2D6 variant } \\
\text { alleles in responder vs. } \\
\text { refractory group }\end{array}$ & 157 & $\begin{array}{l}\text { CYP2D6 genotyping; } \\
\text { Patient assessment for } \\
\text { adverse events and tumor } \\
\text { response after } 4,8,16 \text { and } \\
\quad 24 \text { weeks }\end{array}$ & $\begin{array}{l}\text { Wild-type } C Y P 2 D 6 \text { was present in } 113 \text { of the patients; } \\
62.0 \% \text { in the refractory group and } 82.1 \% \text { in } \\
\text { responders. In } 44 \text { patients, } C Y P 2 D 6 \text { polymorphisms } \\
\text { were detected: } 30 \text { of them were refractory }(68.2 \%) \\
\text { and } 14 \text { were responders }(31.8 \%) \text {. CYP } 2 D 6^{*} 3 \text { and }{ }^{*} 4 \\
\text { were the most common } C Y P 2 D 6 \text { variants detected in } \\
\text { the refractory group }(86.7 \%) \text {. CYP } D 6^{*} 10{ }^{*} 10 \text { and } \\
{ }^{*} 10 / 3 \text { were the most common variant diplotypes } \\
(85.7 \%) \text { in the responders group. }\end{array}$ \\
\hline He et al., 2020 [78] & $\begin{array}{l}\text { Breast cancer-specific } \\
\text { mortality }\end{array}$ & 1309 & CYP2D6 genotyping; & $\begin{array}{l}\text { Patients genotyped as PM and UM show worse } \\
\text { prognosis compared to NMs under standard } \\
\text { tamoxifen dosage ( } 20 \mathrm{mg} \text { /day) (HR: } 2.59,95 \% \text { CI } \\
\text { 1.01-6.67 and HR: } 4.52,95 \% \text { CI } 1.42-14.37 \\
\text { respectively). }\end{array}$ \\
\hline $\begin{array}{c}\text { Sanchez-Spitman et al., } 2019 \\
\text { [89] }\end{array}$ & Relapse-free survival & 667 & $\begin{array}{c}\text { CYP2D6 genotyping; } \\
\text { prospective CYPTAM } \\
\text { study using Cox regression } \\
\text { analysis. }\end{array}$ & $\begin{array}{l}\text { No significant difference in RFS between combined } \\
\text { groups of PMs + IMs + hetEMS and NMs + UMs } \\
(p=0.944) \text {. } \\
\text { Of note: This study was seriously criticized for several } \\
\text { reasons. }\end{array}$ \\
\hline $\begin{array}{c}\text { Rangel-Méndez et al., } 2020 \\
\text { [93] }\end{array}$ & Breast cancer-free survival & 71 & $\begin{array}{c}\text { CYP2D6 genotyping; } \\
\text { retrospective study, using } \\
\text { Kaplan-Meier method and } \\
\text { log-rank test to estimate } \\
\text { BCFS }\end{array}$ & $\begin{array}{l}\text { No difference in BCFS and recurrence risk between } \\
\text { combined group of NMs + UMs and PMs }(p=0.45) \\
\text { and IMs }(p=0.55) \text {. }\end{array}$ \\
\hline Tamura et al., 2019 [73] & $\begin{array}{l}\text { Progression-free survival rate } \\
\text { at } 6 \text { months }\end{array}$ & 186 & $\begin{array}{l}\text { CYP2D6 genotyping; } \\
\text { A randomized, open-label, } \\
\text { multicenter, phase II study. }\end{array}$ & $\begin{array}{l}\text { No significant difference in PFS rate at } 6 \text { months } \\
\text { between increased dosage arm and regular dosage } \\
\text { arm }(67,6 \% \text { vs. } 66,7 \%) \text {. Survival curves did not } \\
\text { significantly differ }(p=0.15) \text {. }\end{array}$ \\
\hline
\end{tabular}

\section{Conclusions}

CYP2D6 is the main enzyme in the conversion of the prodrug tamoxifen into its most important metabolite endoxifen. Currently, a plasma concentration endoxifen of 5.97 $\mathrm{ng} / \mathrm{mL}$ is maintained to indicate the sufficient efficacy of tamoxifen treatment. Patients with reduced CYP2D6 activity due to genetic variations often fail to reach this limit. Tamoxifen dose increments in these CYP2D6 compromised patients result in higher plasma concentrations of endoxifen without a higher frequency of ADRs. In addition to the CYP2D6 genotype, additional factors also seem to influence endoxifen levels, such as treatment adherence and drug-drug interactions, for example caused by the concomitant use of (strong) CYP2D6 inhibitors. In the last years, various prospective and retrospective studies were performed to examine the association between CYP2D6 genotype and prognosis in (ER-positive) breast cancer patients, which led to, again, contradictory results. Some of these studies have been criticized, mainly because they were neither designed nor statistically powered to answer specific pharmacogenetic questions. Between 2018 and 2021, two studies provided evidence for a relation between CYP2D6 genotype and breast cancer recurrence as well as breast cancer-specific mortality after tamoxifen treatment. In that same period, four studies reported no association with clinical outcome in tamoxifen treatment. Therefore, it seems that the controversy regarding the association of CYP2D6 genotype and tamoxifen-related clinical outcome continues. In our opinion, this controversy will exist up until large randomized control trials will be performed.

Author Contributions: T.A.M.M., M.d.W., M.d.R., R.D., R.H.J.M., and R.H.N.v.S. discussed and wrote the manuscript. T.A.M.M., M.d.W. and R.H.N.v.S. generated figures and tables. All authors have read and agreed to the published version of the manuscript.

Funding: This research received no external funding.

Institutional Review Board Statement: Not applicable.

Informed Consent Statement: Not applicable. 


\section{Data Availability Statement: Not applicable.}

Conflicts of Interest: The authors declare no conflict of interest.

\section{References}

1. Jordan, V.C. Tamoxifen as the first targeted long-term adjuvant therapy for breast cancer. Endocr. Relat. Cancer 2014, 21, R235-R246. [CrossRef]

2. Briest, S.; Stearns, V. Tamoxifen metabolism and its effect on endocrine treatment of breast cancer. Clin. Adv. Hematol. Oncol. 2009, 7, 185-192. [PubMed]

3. Jordan, V.C. Fourteenth Gaddum Memorial Lecture. A current view of tamoxifen for the treatment and prevention of breast cancer. Br. J. Pharm. 1993, 110, 507-517. [CrossRef]

4. Osborne, C.K. Tamoxifen in the treatment of breast cancer. N. Engl. J. Med. 1998, 339, 1609-1618. [CrossRef] [PubMed]

5. Dean, L. Tamoxifen therapy and CYP2D6 genotype. In Medical Genetics Summaries [Internet]; Pratt, V.M., Pirmohamed, M., Eds.; National Center for Biotechnology Information (US): Bethesda, MD, USA, 2014.

6. Binkhorst, L.; Bannink, M.; de Bruijn, P.; Ruit, J.; Droogendijk, H.; van Alphen, R.J.; den Boer, T.D.; Lam, M.H.; Jager, A.; van Gelder, T.; et al. Augmentation of endoxifen exposure in tamoxifen-treated women following SSRI switch. Clin. Pharm. 2016, 55, 249-255. [CrossRef] [PubMed]

7. Binkhorst, L.; Kloth, J.S.L.; de Wit, A.S.; de Bruijn, P.; Lam, M.H.; Chaves, I.; Burger, H.; van Alphen, R.J.; Hamberg, P.; van Schaik, R.H.N.; et al. Circadian variation in tamoxifen pharmacokinetics in mice and breast cancer patients. Breast Cancer Res. Treat. 2015, 152, 119-128. [CrossRef]

8. Braal, C.L.; Hussaarts, K.; Seuren, L.; Oomen-de Hoop, E.; de Bruijn, P.; Buck, S.A.J.; Bos, M.; Thijs-Visser, M.F.; Zuetenhorst, H.J.M.; Mathijssen-van Stein, D.; et al. Influence of green tea consumption on endoxifen steady-state concentration in breast cancer patients treated with tamoxifen. Breast Cancer Res. Treat. 2020, 184, 107-113. [CrossRef]

9. Hussaarts, K.; Hurkmans, D.P.; Oomen-de Hoop, E.; van Harten, L.J.; Berghuis, S.; van Alphen, R.J.; Spierings, L.E.A.; van Rossum-Schornagel, Q.C.; Vastbinder, M.B.; van Schaik, R.H.N.; et al. Impact of curcumin (with or without piperine) on the pharmacokinetics of tamoxifen. Cancers 2019, 11, 403. [CrossRef]

10. Mueller-Schoell, A.; Klopp-Schulze, L.; Schroth, W.; Mürdter, T.; Michelet, R.; Brauch, H.; Huisinga, W.; Joerger, M.; Neven, P.; Koolen, S.L.W.; et al. Obesity alters endoxifen plasma levels in young breast cancer patients: A pharmacometric simulation approach. Clin. Pharmacol. Ther. 2020, 108, 661-670. [CrossRef]

11. Roden, D.M.; McLeod, H.L.; Relling, M.V.; Williams, M.S.; Mensah, G.A.; Peterson, J.F.; Van Driest, S.L. Pharmacogenomics. Lancet 2019, 394, 521-532. [CrossRef]

12. FDA. Table of Pharmacogenetic Associations. Available online: https://www.fda.gov/medical-devices/precision-medicine/ table-pharmacogenetic-associations (accessed on 26 October 2020).

13. Henricks, L.M.; Lunenburg, C.; de Man, F.M.; Meulendijks, D.; Frederix, G.W.J.; Kienhuis, E.; Creemers, G.J.; Baars, A.; Dezentjé, V.O.; Imholz, A.L.T.; et al. DPYD genotype-guided dose individualisation of fluoropyrimidine therapy in patients with cancer: A prospective safety analysis. Lancet Oncol. 2018, 19, 1459-1467. [CrossRef]

14. Jin, Y.; Desta, Z.; Stearns, V.; Ward, B.; Ho, H.; Lee, K.H.; Skaar, T.; Storniolo, A.M.; Li, L.; Araba, A.; et al. CYP2D6 genotype, antidepressant use, and tamoxifen metabolism during adjuvant breast cancer treatment. J. Natl. Cancer Inst. 2005, $97,30-39$. [CrossRef]

15. Goetz, M.P.; Rae, J.M.; Suman, V.J.; Safgren, S.L.; Ames, M.M.; Visscher, D.W.; Reynolds, C.; Couch, F.J.; Lingle, W.L.; Flockhart, D.A.; et al. Pharmacogenetics of tamoxifen biotransformation is associated with clinical outcomes of efficacy and hot flashes. $J$. Clin. Oncol. 2005, 23, 9312-9318. [CrossRef] [PubMed]

16. Rae, J.M.; Goetz, M.P.; Hayes, D.F.; Ingle, J.N.; Li, L.; Storniolo, A.M.; Stearns, V.; Flockhart, D.A. CYP2D6 genotype and tamoxifen response. Breast Cancer Res. 2005, 7, E6. [CrossRef]

17. Goetz, M.P.; Sangkuhl, K.; Guchelaar, H.J.; Schwab, M.; Province, M.; Whirl-Carrillo, M.; Symmans, W.F.; McLeod, H.L.; Ratain, M.J.; Zembutsu, H.; et al. Clinical Pharmacogenetics Implementation Consortium (CPIC) guideline for CYP2D6 and tamoxifen therapy. Clin. Pharmacol. Ther. 2018, 103, 770-777. [CrossRef]

18. Cardoso, F.; Kyriakides, S.; Ohno, S.; Penault-Llorca, F.; Poortmans, P.; Rubio, I.T.; Zackrisson, S.; Senkus, E.; ESMO Guidelines Committee. Early breast cancer: ESMO Clinical Practice Guidelines for diagnosis, treatment and follow-up. Ann. Oncol. 2019, 30, 1194-1220. [CrossRef]

19. Regan, M.M.; Leyland-Jones, B.; Bouzyk, M.; Pagani, O.; Tang, W.; Kammler, R.; Dell'orto, P.; Biasi, M.O.; Thürlimann, B.; Lyng, M.B.; et al. CYP2D6 genotype and tamoxifen response in postmenopausal women with endocrine-responsive breast cancer: The breast international group 1-98 trial. J. Natl. Cancer Inst. 2012, 104, 441-451. [CrossRef]

20. Rae, J.M.; Drury, S.; Hayes, D.F.; Stearns, V.; Thibert, J.N.; Haynes, B.P.; Salter, J.; Sestak, I.; Cuzick, J.; Dowsett, M.; et al. CYP2D6 and UGT2B7 genotype and risk of recurrence in tamoxifen-treated breast cancer patients. J. Natl. Cancer Inst. 2012, 104, 452-460. [CrossRef] [PubMed]

21. Kelly, C.M.; Pritchard, K.I. CYP2D6 genotype as a marker for benefit of adjuvant tamoxifen in postmenopausal women: Lessons learned. J. Natl. Cancer Inst. 2012, 104, 427-428. [CrossRef] [PubMed]

22. Stanton, V., Jr. Re: CYP2D6 genotype and tamoxifen response in postmenopausal women with endocrine-responsive breast cancer: The Breast International Group 1-98 trial. J. Natl. Cancer Inst. 2012, 104, 1265-1266. [CrossRef] 
23. Pharoah, P.D.; Abraham, J.; Caldas, C. Re: CYP2D6 genotype and tamoxifen response in postmenopausal women with endocrineresponsive breast cancer: The Breast International Group 1-98 trial and Re: CYP2D6 and UGT2B7 genotype and risk of recurrence in tamoxifen-treated breast cancer patients. J. Natl. Cancer Inst. 2012, 104, 1263-1264. [CrossRef] [PubMed]

24. Nakamura, Y.; Ratain, M.J.; Cox, N.J.; McLeod, H.L.; Kroetz, D.L.; Flockhart, D.A. Re: CYP2D6 genotype and tamoxifen response in postmenopausal women with endocrine-responsive breast cancer: The Breast International Group 1-98 trial. J. Natl. Cancer Inst. 2012, 104, 1264. [CrossRef]

25. Province, M.A.; Goetz, M.P.; Brauch, H.; Flockhart, D.A.; Hebert, J.M.; Whaley, R.; Suman, V.J.; Schroth, W.; Winter, S.; Zembutsu, H.; et al. CYP2D6 genotype and adjuvant tamoxifen: Meta-analysis of heterogeneous study populations. Clin. Pharmacol. Ther. 2014, 95, 216-227. [CrossRef]

26. Jung, J.A.; Lim, H.S. Association between CYP2D6 genotypes and the clinical outcomes of adjuvant tamoxifen for breast cancer: A meta-analysis. Pharmacogenomics 2014, 15, 49-60. [CrossRef]

27. Zeng, Z.; Liu, Y.; Liu, Z.; You, J.; Chen, Z.; Wang, J.; Peng, Q.; Xie, L.; Li, R.; Li, S.; et al. CYP2D6 polymorphisms influence tamoxifen treatment outcomes in breast cancer patients: A meta-analysis. Cancer Chemother. Pharm. 2013, 72, 287-303. [CrossRef]

28. Lum, D.W.; Perel, P.; Hingorani, A.D.; Holmes, M.V. CYP2D6 genotype and tamoxifen response for breast cancer: A systematic review and meta-analysis. PLoS ONE 2013, 8, e76648. [CrossRef]

29. Cronin-Fenton, D.P.; Damkier, P.; Lash, T.L. Metabolism and transport of tamoxifen in relation to its effectiveness: New perspectives on an ongoing controversy. Future Oncol. 2014, 10, 107-122. [CrossRef]

30. WHO. Cancer Tomorrow. Available online: https: / gco.iarc.fr $/$ tomorrow $/$ graphic-isotype?type=0\&type_sex=0\&mode $=$ population $\&$ sex $=2 \&$ populations $=900 \&$ cancers $=20 \& a g e \_$group $=$value \&apc_male $=0 \& a p c \_f e m a l e=0 \&$ single_unit $=500000$ \&print $=0$ (accessed on 19 September 2020).

31. Saladores, P.H.; Precht, J.C.; Schroth, W.; Brauch, H.; Schwab, M. Impact of metabolizing enzymes on drug response of endocrine therapy in breast cancer. Expert Rev. Mol. Diagn. 2013, 13, 349-365. [CrossRef]

32. Shagufta; Ahmad, I. Tamoxifen a pioneering drug: An update on the therapeutic potential of tamoxifen derivatives. Eur. J. Med. Chem. 2018, 1443, 515-531. [CrossRef] [PubMed]

33. Bradford, L.D. CYP2D6 allele frequency in European Caucasians, Asians, Africans and their descendants. Pharmacogenomics 2002, 3, 229-243. [CrossRef] [PubMed]

34. McKusick, V.A.; Hamosh, A. Cytochrome P450, Subfamily IID, Polypeptide 6; CYP2D6. Available online: https:/ / www.omim. org/entry/124030 (accessed on 29 September 2020).

35. PharmVar. Cyp2d6. Available online: https:/ /www.pharmvar.org/gene/cyp2d6 (accessed on 29 September 2020).

36. Sachse, C.; Brockmöller, J.; Bauer, S.; Roots, I. Cytochrome P450 2D6 variants in a Caucasian population: Allele frequencies and phenotypic consequences. Am. J. Hum. Genet. 1997, 60, 284-295.

37. Hicks, J.K.; Swen, J.J.; Gaedigk, A. Challenges in CYP2D6 phenotype assignment from genotype data: A critical assessment and call for standardization. Curr. Drug Metab. 2014, 15, 218-232. [CrossRef] [PubMed]

38. CPIC. Final Consensus CYP2D6 Genotype to Phenotype Table-March. 2019. Available online: https://cpicpgx.org/wp-content/ uploads/2019/03/Final-Consensus-CYP2D6-genotype-to-phenotype-table_final_Mar2019.pdf (accessed on 29 September 2020).

39. Caudle, K.E.; Sangkuhl, K.; Whirl-Carrillo, M.; Swen, J.J.; Haidar, C.E.; Klein, T.E.; Gammal, R.S.; Relling, M.V.; Scott, S.A.; Hertz, D.L.; et al. Standardizing CYP2D6 genotype to phenotype translation: Consensus recommendations from the Clinical Pharmacogenetics Implementation Consortium and Dutch Pharmacogenetics Working Group. Clin. Transl. Sci. 2020, 13, 116-124. [CrossRef] [PubMed]

40. Lee, C.I.; Low, S.K.; Maldonado, R.; Fox, P.; Balakrishnar, B.; Coulter, S.; de Bruijn, P.; Koolen, S.L.W.; Gao, B.; Lynch, J.; et al. Simplified phenotyping of CYP2D6 for tamoxifen treatment using the N-desmethyl-tamoxifen/ endoxifen ratio. Breast 2020, 54, 229-234. [CrossRef]

41. Binkhorst, L.; Mathijssen, R.H.; Jager, A.; van Gelder, T. Individualization of tamoxifen therapy: Much more than just CYP2D6 genotyping. Cancer Treat. Rev. 2015, 41, 289-299. [CrossRef]

42. Binkhorst, L.; van Gelder, T.; Mathijssen, R.H. Individualization of tamoxifen treatment for breast carcinoma. Clin. Pharmacol. 2012, 92, 431-433. [CrossRef] [PubMed]

43. Helland, T.; Henne, N.; Bifulco, E.; Naume, B.; Borgen, E.; Kristensen, V.N.; Kvaløy, J.T.; Lash, T.L.; Alnæs, G.I.G.; van Schaik, R.H.; et al. Serum concentrations of active tamoxifen metabolites predict long-term survival in adjuvantly treated breast cancer patients. Breast Cancer Res. 2017, 19, 125. [CrossRef]

44. De Vries Schultink, A.H.M.; Huitema, A.D.R.; Beijnen, J.H. Therapeutic Drug Monitoring of endoxifen as an alternative for CYP2D6 genotyping in individualizing tamoxifen therapy. Breast 2018, 42, 38-40. [CrossRef]

45. de Graan, A.J.; Teunissen, S.F.; de Vos, F.Y.; Loos, W.J.; van Schaik, R.H.; de Jongh, F.E.; de Vos, A.I.; van Alphen, R.J.; van der Holt, B.; Verweij, J.; et al. Dextromethorphan as a phenotyping test to predict endoxifen exposure in patients on tamoxifen treatment. J. Clin. Oncol. 2011, 29, 3240-3246. [CrossRef]

46. Opdam, F.L.; Modak, A.S.; Gelderblom, H.; Guchelaar, H.J. Further characterization of a ${ }^{13}$ C-dextromethorphan breath test for CYP2D6 phenotyping in breast cancer patients on tamoxifen therapy. J. Breath Res. 2015, 9, 026003. [CrossRef]

47. Gusella, M.; Pasini, F.; Corso, B.; Bertolaso, L.; De Rosa, G.; Falci, C.; Modena, Y.; Barile, C.; Da Corte, Z.D.; Fraccon, A.; et al. Predicting steady-state endoxifen plasma concentrations in breast cancer patients by CYP2D6 genotyping or phenotyping. Which approach is more reliable? Pharm. Res. Perspect. 2020, 8, e00646. [CrossRef] [PubMed] 
48. Johänning, J.; Kröner, P.; Thomas, M.; Zanger, U.M.; Nörenberg, A.; Eichelbaum, M.; Schwab, M.; Brauch, H.; Schroth, W.; Mürdter, T.E. The formation of estrogen-like tamoxifen metabolites and their influence on enzyme activity and gene expression of ADME genes. Arch. Toxicol. 2018, 92, 1099-1112. [CrossRef] [PubMed]

49. Mürdter, T.E.; Schroth, W.; Bacchus-Gerybadze, L.; Winter, S.; Heinkele, G.; Simon, W.; Fasching, P.A.; Fehm, T.; German, T.; Group, A.I.C.; et al. Activity levels of tamoxifen metabolites at the estrogen receptor and the impact of genetic polymorphisms of phase I and II enzymes on their concentration levels in plasma. Clin. Pharmacol. 2011, 89, 708-717. [CrossRef] [PubMed]

50. Saladores, P.; Mürdter, T.; Eccles, D.; Chowbay, B.; Zgheib, N.K.; Winter, S.; Ganchev, B.; Eccles, B.; Gerty, S.; Tfayli, A.; et al. Tamoxifen metabolism predicts drug concentrations and outcome in premenopausal patients with early breast cancer. Pharm. J. 2015, 15, 84-94. [CrossRef] [PubMed]

51. Manish, M.; Lynn, A.M.; Mishra, S. Cytochrome P450 2C9 polymorphism: Effect of amino acid substitutions on protein flexibility in the presence of tamoxifen. Comput. Biol. Chem. 2020, 84, 107166. [CrossRef] [PubMed]

52. Sanchez Spitman, A.B.; Moes, D.; Gelderblom, H.; Dezentje, V.O.; Swen, J.J.; Guchelaar, H.J. Effect of CYP3A4*22, CYP3A5*3, and CYP3A combined genotypes on tamoxifen metabolism. Eur. J. Clin. Pharm. 2017, 73, 1589-1598. [CrossRef]

53. Puszkiel, A.; Arellano, C.; Vachoux, C.; Evrard, A.; Le Morvan, V.; Boyer, J.C.; Robert, J.; Delmas, C.; Dalenc, F.; Debled, M.; et al. Model-based quantification of impact of genetic polymorphisms and co-medications on pharmacokinetics of tamoxifen and six metabolites in breast cancer. Clin. Pharmacol. 2020. [CrossRef]

54. Lim, J.S.; Sutiman, N.; Muerdter, T.E.; Singh, O.; Cheung, Y.B.; Ng, R.C.; Yap, Y.S.; Wong, N.S.; Ang, P.C.; Dent, R.; et al. Association of CYP2C19*2 and associated haplotypes with lower norendoxifen concentrations in tamoxifen-treated Asian breast cancer patients. Br. J. Clin. Pharm. 2016, 81, 1142-1152. [CrossRef]

55. Ruiter, R.; Bijl, M.J.; van Schaik, R.H.; Berns, E.M.; Hofman, A.; Coebergh, J.W.; van Noord, C.; Visser, L.E.; Stricker, B.H. CYP2C19*2 polymorphism is associated with increased survival in breast cancer patients using tamoxifen. Pharmacogenomics 2010, 11, 1367-1375. [CrossRef] [PubMed]

56. Van Schaik, R.H.; Kok, M.; Sweep, F.C.; van Vliet, M.; van Fessem, M.; Meijer-van Gelder, M.E.; Seynaeve, C.; Lindemans, J.; Wesseling, J.; Van 't Veer, L.J.; et al. The CYP2C19*2 genotype predicts tamoxifen treatment outcome in advanced breast cancer patients. Pharmacogenomics 2011, 12, 1137-1146. [CrossRef] [PubMed]

57. Beelen, K.; Opdam, M.; Severson, T.M.; Koornstra, R.H.; Vincent, A.D.; Hauptmann, M.; van Schaik, R.H.; Berns, E.M.; Vermorken, J.B.; van Diest, P.J.; et al. CYP2C19 2 predicts substantial tamoxifen benefit in postmenopausal breast cancer patients randomized between adjuvant tamoxifen and no systemic treatment. Breast Cancer Res. Treat. 2013, 139, 649-655. [CrossRef] [PubMed]

58. Powers, J.L.; Buys, S.S.; Fletcher, D.; Melis, R.; Johnson-Davis, K.L.; Lyon, E.; Malmberg, E.M.; McMillin, G.A. Multigene and drug interaction approach for tamoxifen metabolite patterns reveals possible involvement of CYP2C9, CYP2C19, and ABCB1. J. Clin. Pharm. 2016, 56, 1570-1581. [CrossRef] [PubMed]

59. Khan, B.A.; Robinson, R.; Fohner, A.E.; Muzquiz, L.I.; Schilling, B.D.; Beans, J.A.; Olnes, M.J.; Trawicki, L.; Frydenlund, H.; Laukes, C.; et al. Cytochrome P450 genetic variation associated with tamoxifen biotransformation in american indian and alaska native people. Clin. Transl. Sci. 2018, 11, 312-321. [CrossRef] [PubMed]

60. Damkier, P.; Kjærsgaard, A.; Barker, K.A.; Cronin-Fenton, D.; Crawford, A.; Hellberg, Y.; Janssen, E.A.M.; Langefeld, C.; Ahern, T.P.; Lash, T.L. CYP2C19*2 and CYP2C19*17 variants and effect of tamoxifen on breast cancer recurrence: Analysis of the International Tamoxifen Pharmacogenomics Consortium dataset. Sci. Rep. 2017, 7, 7727. [CrossRef]

61. Lim, J.S.; Chen, X.A.; Singh, O.; Yap, Y.S.; Ng, R.C.; Wong, N.S.; Wong, M.; Lee, E.J.; Chowbay, B. Impact of CYP2D6, CYP3A5, CYP2C9 and CYP2C19 polymorphisms on tamoxifen pharmacokinetics in Asian breast cancer patients. Br. J. Clin. Pharm. 2011, 71, 737-750. [CrossRef]

62. Ahmed, J.H.; Makonnen, E.; Fotoohi, A.; Aseffa, A.; Howe, R.; Aklillu, E. CYP2D6 genotype predicts plasma concentrations of tamoxifen metabolites in Ethiopian breast cancer patients. Cancers 2019, 11, 1353. [CrossRef]

63. Cronin-Fenton, D.P.; Damkier, P. Tamoxifen and CYP2D6: A controversy in pharmacogenetics. Adv. Pharm. 2018, 83, 65-91.

64. Lazarus, P.; Blevins-Primeau, A.S.; Zheng, Y.; Sun, D. Potential role of UGT pharmacogenetics in cancer treatment and prevention: Focus on tamoxifen. Ann. N. Y. Acad. Sci. 2009, 1155, 99-111. [CrossRef] [PubMed]

65. Sutiman, N.; Lim, J.S.L.; Muerdter, T.E.; Singh, O.; Cheung, Y.B.; Ng, R.C.H.; Yap, Y.S.; Wong, N.S.; Ang, P.C.S.; Dent, R.; et al. Pharmacogenetics of UGT1A4, UGT2B7 and UGT2B15 and their influence on tamoxifen disposition in Asian breast cancer patients. Clin. Pharm. 2016, 55, 1239-1250. [CrossRef]

66. Sanchez-Spitman, A.B.; Dezentjé, V.O.; Swen, J.J.; Moes, D.; Gelderblom, H.; Guchelaar, H.J. Genetic polymorphisms of 3'untranslated region of SULT1A1 and their impact on tamoxifen metabolism and efficacy. Breast Cancer Res. Treat. 2018, 172, 401-411. [CrossRef]

67. Madlensky, L.; Natarajan, L.; Tchu, S.; Pu, M.; Mortimer, J.; Flatt, S.W.; Nikoloff, D.M.; Hillman, G.; Fontecha, M.R.; Lawrence, H.J.; et al. Tamoxifen metabolite concentrations, CYP2D6 genotype, and breast cancer outcomes. Clin. Pharmacol. 2011, 89, 718-725. [CrossRef]

68. Dezentjé, V.O.; Opdam, F.L.; Gelderblom, H.; Hartigh den, J.; Van der Straaten, T.; Vree, R.; Maartense, E.; Smorenburg, C.H.; Putter, H.; Dieudonné, A.S.; et al. CYP2D6 genotype- and endoxifen-guided tamoxifen dose escalation increases endoxifen serum concentrations without increasing side effects. Breast Cancer Res. Treat. 2015, 153, 583-590. [CrossRef] [PubMed] 
69. Sanchez-Spitman, A.B.; Moes, D.A.R.; Swen, J.J.; Dezentjé, V.O.; Lambrechts, D.; Neven, P.; Gelderblom, H.; Guchelaar, H.J. Exposure-response analysis of endoxifen serum concentrations in early-breast cancer. Cancer Chemother. Pharm. 2020, 85, 1141-1152. [CrossRef]

70. Thorén, L.; Lindh, J.D.; Ackehed, G.; Kringen, M.K.; Hall, P.; Bergh, J.; Molden, E.; Margolin, S.; Eliasson, E. Impairment of endoxifen formation in tamoxifen-treated premenopausal breast cancer patients carrying reduced-function CYP2D6 alleles. $\mathrm{Br}$. $J$. Clin. Pharm. 2020. [CrossRef] [PubMed]

71. Nardin, J.M.; Schroth, W.; Almeida, T.A.; Mürdter, T.; Picolotto, S.; Vendramini, E.C.L.; Hoppe, R.; Kogin, J.P.; Miqueleto, D.; de Moraes, S.D.R.; et al. The influences of adherence to tamoxifen and CYP2D6pharmacogenetics on plasma concentrations of the active metabolite (Z)-endoxifen in breast cancer. Clin. Transl. Sci. 2020, 13, 284-292. [CrossRef]

72. Khalaj, Z.; Baratieh, Z.; Nikpour, P.; Schwab, M.; Schaeffeler, E.; Mokarian, F.; Khanahmad, H.; Salehi, R.; Mürdter, T.E.; Salehi, M. Clinical Trial: CYP2D6 related dose escalation of tamoxifen in breast cancer patients with Iranian ethnic background resulted in increased concentrations of tamoxifen and its metabolites. Front. Pharm. 2019, 10, 530. [CrossRef] [PubMed]

73. Tamura, K.; Imamura, C.K.; Takano, T.; Saji, S.; Yamanaka, T.; Yonemori, K.; Takahashi, M.; Tsurutani, J.; Nishimura, R.; Sato, K.; et al. CYP2D6 genotype-guided tamoxifen dosing in hormone receptor-positive metastatic breast cancer (TARGET-1): A randomized, open-label, phase II study. J. Clin. Oncol. 2020, 38, 558-566. [CrossRef]

74. Irvin, W.J., Jr.; Walko, C.M.; Weck, K.E.; Ibrahim, J.G.; Chiu, W.K.; Dees, E.C.; Moore, S.G.; Olajide, O.A.; Graham, M.L.; Canale, S.T;; et al. Genotype-guided tamoxifen dosing increases active metabolite exposure in women with reduced CYP2D6 metabolism: A multicenter study. J. Clin. Oncol. 2011, 29, 3232-3239. [CrossRef]

75. Welzen, M.E.; Dezentjé, V.O.; van Schaik, R.H.; Colbers, A.P.; Guchelaar, H.J.; van Erp, N.P.; den Hartigh, J.; Burger, D.M.; van Laarhoven, H.W. The effect of tamoxifen dose increment in patients with impaired CYP2D6 activity. Drug Monit. 2015, 37, 501-507. [CrossRef]

76. Martinez de Dueñas, E.; Ochoa Aranda, E.; Blancas Lopez-Barajas, I.; Ferrer Magdalena, T.; Bandrés Moya, F.; Chicharro García, L.M.; Gómez Capilla, J.A.; Zafra Ceres, M.; de Haro, T.; Romero Llorens, R.; et al. Adjusting the dose of tamoxifen in patients with early breast cancer and CYP2D6 poor metabolizer phenotype. Breast 2014, 23, 400-406. [CrossRef]

77. Braal, L.; Jager, A.; Lommen, K.M.; Oomen-de Hoop, E.; De Bruijn, P.; Vastbinder, M.B.; Van Rossum-Schornagel, Q.C.; Thijs-Visser, M.F.; Van Alphen, R.J.; Struik, E.M.; et al. 191P Therapeutic drug monitoring of tamoxifen to improve adjuvant treatment of hormone sensitive breast cancer: The TOTAM study. Ann. Oncol. 2020, 31, S303-S339. [CrossRef]

78. He, W.; Grassmann, F.; Eriksson, M.; Eliasson, E.; Margolin, S.; Thorén, L.; Hall, P.; Czene, K. CYP2D6 genotype predicts tamoxifen discontinuation and prognosis in patients with breast cancer. J. Clin. Oncol. 2020, 38, 548-557. [CrossRef]

79. Beijnen, J.H.; Schellens, J.H. Drug interactions in oncology. Lancet Oncol. 2004, 5, 489-496. [CrossRef]

80. Blower, P.; de Wit, R.; Goodin, S.; Aapro, M. Drug-drug interactions in oncology: Why are they important and can they be minimized? Crit. Rev. Oncol. Hematol. 2005, 55, 117-142. [CrossRef]

81. Arafah, A.; Yakout, K.; Rehman, M.U.; Mohammed Alsharif, A.; AlJawadi, M.H.; Al-Omar, H.A. Prevalence of the co-prescription of tamoxifen and CYP2D6 inhibitors in Saudi population: A cross sectional study. Saudi Pharm. J. 2020, 28, 440-444. [CrossRef]

82. Borges, S.; Desta, Z.; Li, L.; Skaar, T.C.; Ward, B.A.; Nguyen, A.; Jin, Y.; Storniolo, A.M.; Nikoloff, D.M.; Wu, L.; et al. Quantitative effect of CYP2D6 genotype and inhibitors on tamoxifen metabolism: Implication for optimization of breast cancer treatment. Clin. Pharmacol. 2006, 80, 61-74. [CrossRef]

83. Stearns, V.; Johnson, M.D.; Rae, J.M.; Morocho, A.; Novielli, A.; Bhargava, P.; Hayes, D.F.; Desta, Z.; Flockhart, D.A. Active tamoxifen metabolite plasma concentrations after coadministration of tamoxifen and the selective serotonin reuptake inhibitor paroxetine. J. Natl. Cancer Inst. 2003, 95, 1758-1764. [CrossRef]

84. Monte, A.A.; West, K.; McDaniel, K.T.; Flaten, H.K.; Saben, J.; Shelton, S.; Abdelmawla, F.; Bushman, L.R.; Williamson, K.; Abbott, D.; et al. CYP2D6 genotype phenotype discordance due to drug-drug interaction. Clin. Pharmacol. 2018, 104, 933-939. [CrossRef] [PubMed]

85. Del Re, M.; Citi, V.; Crucitta, S.; Rofi, E.; Belcari, F.; van Schaik, R.H.; Danesi, R. Pharmacogenetics of CYP2D6 and tamoxifen therapy: Light at the end of the tunnel? Pharm. Res. 2016, 107, 398-406. [CrossRef] [PubMed]

86. Dezentjé, V.O.; Guchelaar, H.J.; Nortier, J.W.; van de Velde, C.J.; Gelderblom, H. Clinical implications of CYP2D6 genotyping in tamoxifen treatment for breast cancer. Clin. Cancer Res. 2009, 15, 15-21. [CrossRef] [PubMed]

87. Brooks, J.D.; Comen, E.A.; Reiner, A.S.; Orlow, I.; Leong, S.F.; Liang, X.; Mellemkjær, L.; Knight, J.A.; Lynch, C.F.; John, E.M.; et al. CYP2D6 phenotype, tamoxifen, and risk of contralateral breast cancer in the WECARE Study. Breast Cancer Res. 2018, 20, 149. [CrossRef]

88. Malash, I.; Mansour, O.; Shaarawy, S.; Abdellateif, M.S.; Omar, A.; Gaafer, R.; Zekri, A.N.; Ahmed, O.S.; Bahnassy, A. The Role of CYP2D6 Polymorphisms in Determining Response to Tamoxifen in Metastatic Breast Cancer Patients: Review and Egyptian Experience. Asian Pac. J. Cancer Prev. 2020, 21, 3619-3625. [CrossRef]

89. Sanchez-Spitman, A.; Dezentjé, V.; Swen, J.; Moes, D.; Böhringer, S.; Batman, E.; van Druten, E.; Smorenburg, C.; van Bochove, A.; Zeillemaker, A.; et al. Tamoxifen pharmacogenetics and metabolism: Results from the prospective CYPTAM study. J. Clin. Oncol. 2019, 37, 636-646. [CrossRef]

90. Goetz, M.P.; Suman, V.J.; Nakamura, Y.; Kiyotani, K.; Jordan, V.C.; Ingle, J.N. Tamoxifen metabolism and breast cancer recurrence: A question unanswered by CYPTAM. J. Clin. Oncol. 2019, 37, 1982-1983. [CrossRef] [PubMed] 
91. Brauch, H.; Schroth, W.; Mürdter, T.; Schwab, M. Tamoxifen pharmacogenetics and metabolism: The same is not the same. J. Clin. Oncol. 2019, 37, 1981-1982. [CrossRef]

92. Braal, C.L.; Beijnen, J.H.; Koolen, S.L.W.; Oomen-de Hoop, E.; Steeghs, N.; Jager, A.; Huitema, A.D.R.; Mathijssen, R.H.J. Relevance of Endoxifen Concentrations: Absence of Evidence Is Not Evidence of Absence. J. Clin. Oncol. 2019, 37, 1980-1981. [CrossRef] [PubMed]

93. Rangel-Méndez, J.A.; Rubi-Castellanos, R.; Ascencio-Montiel, I.J.; Moo-Puc, R.E. CYP2D6 does not impact on breast cancer-free survival in Southeast Mexican patients under tamoxifen treatment. Pers. Med. 2020, 17, 261-270.

94. Hertz, D.L.; Kidwell, K.M.; Hilsenbeck, S.G.; Oesterreich, S.; Osborne, C.K.; Philips, S.; Chenault, C.; Hartmaier, R.J.; Skaar, T.C.; Sikora, M.J.; et al. CYP2D6 genotype is not associated with survival in breast cancer patients treated with tamoxifen: Results from a population-based study. Breast Cancer Res. Treat. 2017, 166, 277-287. [CrossRef] [PubMed] 